\title{
DIFFICULTIES FACING CHALLENGES KOSOVO BUSINESSES FOR INCREASING THEIR COMPETITIVENESS WITH OTHER BUSINESS- ES IN REGION AND ABROAD
}

\author{
Skender Hasani \\ University College "Vision for education", Ahmet Kaqiku, 70000 Ferizaj - Kosovo, \\ skender_hasani@yahoo.com
}

\begin{abstract}
In terms of the global economy emerging economies like Kosovo economy is, face with many difficulties. These difficulties in the ecomomy as a whole have also followed Kosovo Businesses in particular where these businesses are faced with difficulties of different nature as it is lack of financial capital, lack of professional staff wich will continuosly follow economic changes in the region and the world as well as a total lack of infrastructure which has an impact on increasing the competitiveness of these businesses. Kosovo businesses are mostly small businesses which still lacks capital union between a certain numbers of businesses in order that these businesses to be competitive in the global market. These businesses also face with fiscal policies applied so far in Kosovo which did not stimulate their growth and even enhancing the competitiveness of these businesses against other businesses in the region or beyond.

In this paper we have analyzed some aspects of fiscal policies and other economic policies applied in Kosovo which have been faced Kosovo businesses and we will do a comparison of these policies with those that apply in some countries of the region, we will also focus on steps to be taken by those businesses their self which steps would help in increasing the competitiveness of these businesses compared to businesses abroad. Also after analyzing and comparing of several economic and fiscal policies applied in the countries of the region we will recommend some economic and fiscal reforms wich can be made by governmental institutions which reforms will have an impact and would give a new and strong boost in order that Kosovo businesses will increase competitiveness of their products and services and with that also increasing of profitability and rentability.
\end{abstract}

Keywords: Competitiveness, Businesses, Fiscal Policies, Challanges, Reforms.

\section{INTRODUCTION}

Kosovo's economy is a new economy which is going through transition phase with enough difficulties therefore this economy needs substantial reforms that will enable the growth of businesses that would be competitive with other businesses abroad. After the war in Kosovo in 1999 businesses have emerged entirely destroyed from it and a lot of efforts were required in order to start the revitalization of the economy. In the beginning there was a large number of international organizations that have assisted several enterprises financially and in the technical aspects but there was a need for substan- 
tial changes and the economy which was destroyed initially has not been able to resist the pressure and immediate needs.

But over time, substantial changes have been observed, the appearance of a number of new enterprises which have tended to affect the overall economic development of Kosovo. These enterprises have been oriented primarily in trade and services but very little in production and therefore the ratio between import and export has been very high. However there is a small reduction of this difference even further in 2014 according to the official data of Agency for Statistics in Kosovo the ratio between import and export is 87 to 13 in favor of imports. Furthermore this indicates that Kosovo has an urgent need for deep structural reforms in the field of doing business. Reform in the fiscal policy, business credit system with the sole purpose of facilitating and enhancing local productivity because no country can survive if it's greatly oriented towards import.

The structure of businesses in Kosovo is characterized by a large number of small and medium enterprises with limited capacities for major projects and initiatives. Due to the relatively small size of the market, companies that have grown beyond competitiveness were forced to share a part of their activities in the new enterprise in order to maintain market leadership. Such composition of sector offers very favorable conditions for market entry for new companies. The economy can be maintained only with the invention and re-invention of products and services through steady flow of new competitors with ambitions to become leaders in their respective markets. While the general environment of doing business in Kosovo has improved significantly in the last 5 years, and there is no legal obstacle to starting a business within a very short period of time but lack of financial support in the initial stage of businesses has been an "invisible" hindrance that has prevented the creation of new enterprises respectively successful business development of these newly established or existing enterprises.

An important characteristic of the new businesses in Kosovo is also the average age of entrepreneurs is much lower than the average age in other countries. While this has been mainly due to the demographics of the population, according to which Kosovo is ranked as the country with the youngest population in Europe, it also has had an impact on the degree of success of new businesses.

\section{PURPOSE AND THE OBJECTIVES OF THE STUDY}

The purpose of this study was to analyze the possibilities of doing on business in Kosovo including the numerous difficulties faced by Kosovo businesses. So here we have analyzed numerous difficulties and obstacles faced by Kosovo businesses including small institutional support which will help business development of businesses, then the lack of market for their products and services, unfair competition, lack of qualified and skilled staff to assist new businesses with innovative ideas which would provide results in increased reliability in the products and services of Kosovo businesses. Lack of training in various fields, access and cost of raw materials, use of modern equipment, workspace, physical infrastructure, transport, finance, legal, economic and fiscal policies, offer the possibility of analysis, creation and research methods and methodologies to support MSEs.

The basic aim of this paper is diagnosing the current situation in Kosovo enterprises; identify problems, obstacles and barriers that suffocate the development of their activities, identifying both the needs and demands of the community to improve the situation, advancing the development process and positive development trends in strategic terms.

Another goal of this research is to produce results relevant to the current situation, structure, problems, difficulties and to measure the trend of development of micro, small and medium enterprises, to determine the criteria and advanced recommendations for the possibility of supporting their development.

A particular focus of this research was to identify barriers to doing business. In this context the Kosovar entrepreneurs had the opportunity to respond specifically related to obstacles which they consider to be substantial to exercise their activity, to increase their financial sustainability and to have a greater participation of their products and services not only in the market Kosovo but also beyond.

Kosovo remains the poorest economy in the region and faces high levels of poverty, massive unemployment (which on average is estimated to be $45 \%$, in contrast to the example of Macedonia and Albania with $37 \%$ to $14 \%$ ), heavy dependence on imports and very small sector of export, and lack of energy. Gross national income (GNI) per capita estimated at $\$ 3.520$, and thus Kosovo is ranked 93 in the world, behind Macedonia, Albania, Serbia and Bosnia and Hercegovina. 
The economy continued with the growth rate of $3-5 \%$ for nearly a decade until 2011 . Agency for Statistics of Kosovo (ASK) estimated that during the three-year (2013-2015) the economy will grow on average $4.7 \%$ that is the highest average rate among the economies of Eastern Europe 1 . However, the growth rate is not enough at all to have visible effects on poverty and unemployment. For example, the World Bank or estimated that Kosovo will have to at least double the growth rate and to reach at least $12 \%$ growth per year for a decade to reach the current level of Gross Domestic Product (GDP) of Montenegro per capita. In short, the gap in income between Kosovo and other countries of Eastern Europe is likely to remain deep, despite the greater growth.

Economic activity is concentrated mainly in the services sector which is expanding as a result of the high level of remittances and the large international presence in Kosovo. Yet there has been substantial investment in the commodities sector productive trade

Large current deficit (19\% of GDP in 2011) is financed mainly through charities and remittances. In fact, Kosovo is one of the ten countries with the highest level of remittances where $13 \%$ of GDP comes from remittances from abroad. ${ }^{2}$ Both these sources of revenue are fragile and depend on the economic crisis in Europe. Although remittances maintained high levels and remained stable so far, only about $11 \%$ of the money used for investment, whereas most of the money is spent on consumption.

While Kosovo has a negative balance of international trade (nearly $45 \%$ of GDP in 2011) it has been projected that exports will grow much faster than imports, and as a result of this imbalance would improve at least slightly. Inflation remains low, as a result of the use of the euro which had limited monetary misbalance and this has contributed to relatively sound fiscal policies. The recent global financial crisis has had limited impact on the Kosovo economy as a result of the low level of integration of the local economy with international markets.

Creating an environment for sustainable economic growth and improving competitiveness has been the main focus for Kosovo since the transition from crisis in development. Increased investment and increased employment in the private sector to meet the challenges and to mitigate obstacles to build a healthy economy with a broad-base.

Institutions of KG that are responsible for maintaining macro-economic stability have done admirable work to ensure that Kosovo will remain one of the countries with greater fiscal and financial stability in the region.

Substantial progress has been achieved in the "Doing Business Index" of the World Bank where Kosovo has progressed enough from year to year. This progress has been achieved after many efforts by the government, but when we analyze the situation of our neighbors and competitiveness, it is clear that Kosovo still has work to do because Macedonia is ranked 23, 51 Montenegro, Albania and Serbia 8586 . Now the challenge is to make improvements in the general regulatory environment so that Kosovo creates a strong private sector and attracts direct foreign investment.

For example, Kosovo still suffers from excessive government regulation of private economic activities through licenses, permits and other obstructive processes in the local and central level which increase the cost of doing business and makes Kosovo less competitive in attracting new investments.

Kosovo has a clear opportunity to move towards faster growth led by the private sector, given that its products have free access to the European Union market and in countries that have signed the Central European Free Trade Agreement (CEFTA ). Unlocking this potential will involve three factors of production which now stand doing nothing: work, land, and energy and minerals. Diversification of the economy and increased investment in the private sector is a concept that should be developed in a permanent manner in Kosovo. Therefore Kosovo needs to build the capacity for sound economic governance, bearing in mind not only the best implementation of reforms ( through assistance of relatively good legal and regulatory framework which should actually be applied correctly), but also improve the management of public finances, growth in access to credit, attracting foreign investment, increase private sector participation in the construction of public infrastructure and the provision of public services, and addressing the needs for training in certain sectors.

\footnotetext{
${ }^{1}$ Statistical Office of Kosovo.(2014).

2 STTIK, Novembar 2014,Pristina.
} 
Recognition of crisis and evaluation of its effects is related to the fact that often the response should be on the block. Businesses which have difficulties and decline due to the business life cycle, as it is generally the construction sector in our country, have other issues compared to the businesses the activity of which is focused on the food sector, or with businesses that are focused on the tourism sector. However, reaction and protection of the interests should be collective. Very often, people of politics, sometimes even the media, and in some cases the businesses, treat problems of the crisis as disconnected, or as biased.

\section{RESEARCH QUESTION - METHODOLOGY OF TREATMENT}

During the preparation of this paper we were based on primary data that I have received from the field directly through a questionnaire which we have sent and received responses from a total of 318 businesses which are doing business in the whole territory of Kosovo. We were also based on secondary data from relevant state institutions, foreign or international organizations which are dealing with the climate of doing analysis on activity in Kosovo as the World Bank, the European Agency for Reconstruction and Development and other institutions who have done analyses and comparisons of doing business in Kosovo and in other countries of the world.

Below in tabular form we provide information on businesses to which we have sent the questionnaires and from which we received the answers to questions prepared by us:

Questions to which the businesses have replied are of different nature and have included a wide range of the problems they face in their daily activity therefore below in tabular form we presented some of the answers we received from questionnaires submitted to these businesses where they answered with one to ten; meaning that the higher the number is the higher is the priority which they estimate to be causing them difficulties and challenges in their activity. For the purposes of this paper for each region we have taken into consideration the average value of the responses from the various respondents.

\begin{tabular}{|l|l|l|l|l|l|l|l|}
\hline Region & Pristina & Gjilan & Peja & Ferizaj & Mitrovica & Prizren & Total \\
\hline Number & 108 & 42 & 36 & 46 & 34 & 52 & 318 \\
\hline
\end{tabular}

Below in the table we will give some information from different types of businesses from survey:

\begin{tabular}{|l|l|l|l|l|l|l|l|}
\hline Region & Pristina & Gjilan & Peja & Ferizaj & Mitrovica & Prizren & Total \\
\hline $\begin{array}{l}\text { Corporate- } \\
\text { Legal person }\end{array}$ & 21 & 8 & 12 & 16 & 10 & 18 & 85 \\
\hline $\begin{array}{l}\text { Private person } \\
-\quad 87 \quad \text { Individual } \\
\text { Business }\end{array}$ & 34 & 24 & 30 & 24 & 34 & 233 \\
\hline Total: & 108 & 42 & 36 & 46 & 34 & 52 & 318 \\
\hline
\end{tabular}

\begin{tabular}{|l|l|l|l|l|l|l|}
\hline Question & Pristina & Gjilan & Peja & Ferizaj & Mitrovica & Prizren \\
\hline Weak legal framework & 2 & 3 & 2.8 & 2.6 & 3.2 & 3.1 \\
\hline $\begin{array}{l}\text { General economical } \\
\text { situation }\end{array}$ & 8 & 8.5 & 7.8 & 7 & 8.4 & 8.3 \\
\hline $\begin{array}{l}\text { Weak application of } \\
\text { law }\end{array}$ & 7 & 6.5 & 6 & 6.4 & 6.5 & 7.2 \\
\hline $\begin{array}{l}\text { High customs and } \\
\text { taxes }\end{array}$ & 5 & 5.5 & 5.8 & 5.2 & 6 & 5.9 \\
\hline $\begin{array}{l}\text { Non loyal compe- } \\
\text { tetiveness }\end{array}$ & 8 & 8.4 & 8.2 & 8.5 & 8.3 & 8.6 \\
\hline Rimbursment of VAT & 3 & 2.5 & 2.6 & 2.8 & 2.8 & 3 \\
\hline Grants and subven- & 8.5 & 8 & 7.8 & 8.4 & 8.3 & 8.5 \\
\hline
\end{tabular}




\begin{tabular}{|l|l|l|l|l|l|l|}
\hline tions from the state & & & & & & \\
\hline Supply with electricity & 7.5 & 8.8 & 9 & 8.6 & 8.4 & 8.2 \\
\hline $\begin{array}{l}\text { Approach in markets } \\
\text { abroad of Kosova }\end{array}$ & 6 & 6.4 & 6 & 5.8 & 5.9 & 6.1 \\
\hline $\begin{array}{l}\text { Limited capacity in } \\
\text { domestic trade }\end{array}$ & 5 & 5.2 & 4.8 & 4.6 & 5.1 & 4.7 \\
\hline $\begin{array}{l}\text { Quality of transport } \\
\text { services }\end{array}$ & 2 & 1.8 & 1.6 & 1.7 & 2.1 & 2.3 \\
\hline Deficit of raw material & 4 & 4.2 & 4.6 & 4.1 & 3.8 & 4.2 \\
\hline High interest rates & 8.6 & 9 & 9.2 & 9.4 & 9.5 & 9.3 \\
\hline
\end{tabular}

\section{ANALYSES - INTERPRETATION OF DATA}

By analyzing data on some of the questions made to 318 businesses throughout Kosovo after receiving their answers and estimates it resulted that according to them some of the serious problems they are facing and which cause numerous difficulties are summarized as follows:

- High interest rates

- General economic situation

- Difficulties with power supply

- Unfair competition between domestic and foreign enterprises

- Non-application of the legislation in a clear manner

- High customs tariffs and tax

- Limited capacity of local market

- Access to foreign markets

- Small Grants and state subventions

Apart from these difficulties a small part of businesses have stated other difficulties which hinder the business development which are:

- Lack of raw material in the country

- Quality of transport services

- Lack of qualified staff

- Compensation of VAT

Based on the responses received from the primary data and the secondary ones we may conclude that there is a need for a serious and emergent approach of relevant state institutions that deal with the establishment of economic and fiscal policies not only to harmonize economic policies with those of other European Union countries but to see the circumstances in which the Kosovar businesses operate in order to enable them a freedom of action that the results of those actions not to be seen for their immediate effect but in the near future or in a distant future as well as their impact entire business environment. Economic and fiscal policies should have priority not only filling the state's budget but to overcome the budgetary deficit and financing the state apparatus, as well as a different approach so that the effects of these policies can be felt in the future with the increase of employment, economic growth, increasing the competitiveness and quality of products and services offered by local businesses.

From the information obtained from the interviews which were conducted with a significant number of businesses we can emphasize that most of them are not satisfied with the conditions that exist for doing business in Kosovo and believe that doing business is very difficult and this does not come as a result of the taxation system in Kosovo because fiscal charges in Kosovo are quite small but this difficulty is caused by other associated elements of business activities such as: 
Considerably high scale informal economy which affects an unfair competition compared to businesses that conduct their activities in accordance with applicable rules and legislation in Kosovo.

Lack of an efficient and reliable judiciary in resolving various disputes between businesses;

Unfavorable loan system for businesses;

Provision of subsidies and grants for a sustainable economy based on disciplines that are most needed and not on the basis of parameters which are not properly analyzed.

These and a number of other factors are also determining factors of the ability of Kosovo businesses to make business and some of these factors are factors on which the government has not been able to affect such as the e amount of remittances but could have had an impact on channeling them in good investments and not in the consumption which is mainly made from imported goods.

The government does not open new jobs but creates the possibility for their opening in this case the unemployment rate will decrease and the reduction of poverty and other chain effects on local businesses as well. Channeling budget in several major infrastructures projects but not in projects that would affect the growth of productive capacity of Kosovo businesses and the reduction of the dependence of imported products are some of the elements which should have been and should be urgently taken by relevant state institutions. Kosovo has a high potential for agricultural production and for building processing capacities of these products which would enable not only the reduction of the import of these products but also the employment growth of a large number of people including those in the agricultural and industrial capacity.

\section{CONCLUSION - RECOMMENDATION}

Given the findings of primary data received from a number of different business enterprises which covered the entire geographical area of the state and has included businesses from different business fields but also with the different organizational structure it resulted that the government has to undertake urgent steps in order to improve the business climate which despite some minor improvements according to the World Bank report it still remains difficult in comparison to what is offered to businesses by the countries in the region and beyond. Therefore in order to increase the competitiveness of local businesses, increasing the quality of their services and products, increase employment and to reduce poverty, there is an urgent need to for changes and reforms to the fiscal system and the entire business conglomerate which is the basis for a strong and stable economy.

Urgent steps to be taken by government institutions are:

1. To provide access to financial resources and loans for Kosovar businesses with lower credit rates and longer return periods if it is used by businesses of other countries. This can be accomplished with the further liberalization of banking market to further enhance the effectiveness of the judiciary for the collateral left by businesses in debt to banks.

2. The creation of a development fund that will help new businesses and existing businesses which allow employment and sustained economic growth.

3. Increase of loyal competition between the different businesses by stimulating the formal economy and the application of punitive measures against the informal one.

4. Training of staff in order to implement the legislation clearly because the ambiguous interpretations allow for different possibilities for abuse and increase of corruption.

5. The reduction of customs duties and other ones for direct foreign investments, production activities in those business areas which employ more workers and help the overall economic development.

6. Sewage of Remittances in economic activity not only in household expenses

7. Improve power supply, to be stable and uninterrupted in order to have continual productivity and lower costs for local products.

\section{REFERENCE LIST}

World Bank Group (2015), Doing Bussines 2015, Economy profile 2015, Kosovo

STTIK, Novembar 2014, Pristina, Kosovo, Funksional ecosystem for New Bussinesses 
Ministry of trade and Indystry of Kosovo, Pristina, 2011, Research of 800 small and medium bussinesses in Kosovo

USAID, 2013, Kosovo 2014 - 2018, Strategy for cooperation and development of country

Statistical Office of Kosovo. (2014). Economic Statistics Gross domestic product in the expenditure approach (2008-2013) ', Pristina, Kosovo

Thematic Roundtable no. 4. (2012), Trade, industry, customs, tax, internal market, competition, consumer protection and health, Pristina, Kosovo

International Monetary Fond, (2013) Republic of Kosovo several selected issues, Strategy for cooperation on USAID for the development of the country of Kosovo 2014 -2018,

Government of Kosovo, (2011) Vision and Action Plan for the Economical Development,

Shyqyri Kelmendi, (2012) Natural Resources, Bases for National Economical Development

USAID. (2012).Study on the effect of the irregular supply of electricity in Kosovo Businesses,

Moujaes, Chadi N.; Najjar, Mazen Ramsay; Shediac, Richard; Ghaleb, Joey, Elastik,

Stable, (2011) Sustainable Benefits from Economic Diversification, Booz \& Company,

World Bank, (2012). World Development Indicators

World Bank, (2013). Doing Business Report

USAID, (2012).Diagnosis of Growth in Kosovo: Analysis of Barriers 